\title{
Enhancement of doxorubicin anti-cancer activity by vascular targeting using IsoDGR/ cytokine-coated nanogold
}

\author{
Angelo Corti ${ }^{1} 2^{*}$, Angelina Sacchi ${ }^{1}$, Anna Maria Gasparri ${ }^{1}$, Matteo Monieri ${ }^{2}$, Giulia Anderluzzi ${ }^{2}$, \\ Barbara Colombo ${ }^{1}$, Alessandro Gori ${ }^{3}$, Anna Mondino ${ }^{4}$ and Flavio Curnis ${ }^{1 *}$ (D)
}

\begin{abstract}
Background: Gold nanospheres tagged with peptides containing isoDGR (isoAsp-Gly-Arg), an av $\beta 3$ integrin binding motif, represent efficient carriers for delivering pro-inflammatory cytokines to the tumor vasculature. We prepared bi- or trifunctional nanoparticles bearing tumor necrosis factor-a (TNF) and/or interleukin-12 (IL12) plus a peptide containing isoDGR, and we tested their anti-cancer effects, alone or in combination with doxorubicin, in tumor-bearing mice.

Results: In vitro biochemical studies showed that both nanodrugs were monodispersed and functional in terms of binding to TNF and IL 12 receptors and to av $\beta 3$. In vivo studies performed in a murine model of fibrosarcoma showed that low doses of bifunctional nanoparticles bearing isoDGR and TNF (corresponding to few nanoparticles per cell) delayed tumor growth and increased the efficacy of doxorubicin without worsening its toxicity. Similar effects were obtained using trifunctional nanoparticles loaded with isoDGR, TNF and IL12. Mechanistic studies showed that nanoparticles bearing isoDGR and TNF could increase doxorubicin penetration in tumors a few hours after injection and caused vascular damage at later time points.
\end{abstract}

Conclusion: IsoDGR-coated gold nanospheres can be exploited as a versatile platform for single- or multi-cytokine delivery to cells of the tumor vasculature. Extremely low doses of isoDGR-coated nanodrugs functionalized with TNF or TNF plus IL12 can enhance doxorubicin anti-tumor activity.

Keywords: IsoAsp-Gly-Arg (isoDGR motif), Avß3 integrin, TNF, IL12, Gold nanoparticles, Tumor vascular targeting

\section{Background}

The major limitation in using cytokines for cancer therapy is often related to their prohibitive toxicity and rapid induction of counter-regulatory mechanisms [1-3]. A growing body of evidence suggests that these obstacles can be overcome by strategies based on ligand-directed delivery of low-dose cytokines

\footnotetext{
*Correspondence: corti.angelo@hsr.it; curnis.flavio@hsr.it

${ }^{1}$ Tumor Biology and Vascular Targeting Unit, Division of Experimental

Oncology, IRCCS San Raffaele Scientific Institute, via Olgettina 58, 20132 Milan, Italy

Full list of author information is available at the end of the article
}

to tumors [4-7]. This approach can be achieved by cytokine conjugation to antibodies or peptide ligands that recognize specific receptors expressed by tumor cells or by other elements of the tumor microenvironment, including tumor vessels $[4,6]$. For example, peptides containing Ans-Gly-Arg (NGR), Arg-Gly-Asp (RGD), or isoAsp-Gly-Arg (isoDGR) sequences selective for CD13 or integrins overexpressed by the tumor vasculature have been exploited as ligands for delivering tumor necrosis factor- $\alpha$ (TNF) [7], interferon (IFN) $\alpha 2 \mathrm{a}$ [8], or IFN $\gamma$ [9] to tumors, consequently improving their therapeutic index $[7,10]$. A prototypical compound belonging to this class of molecules is

c) The Author(s) 2021. This article is licensed under a Creative Commons Attribution 4.0 International License, which permits use, sharing, adaptation, distribution and reproduction in any medium or format, as long as you give appropriate credit to the original author(s) and the source, provide a link to the Creative Commons licence, and indicate if changes were made. The images or other third party material in this article are included in the article's Creative Commons licence, unless indicated otherwise in a credit line to the material. If material is not included in the article's Creative Commons licence and your intended use is not permitted by statutory regulation or exceeds the permitted use, you will need to obtain permission directly from the copyright holder. To view a copy of this licence, visit http://creativeco mmons.org/licenses/by/4.0/. The Creative Commons Public Domain Dedication waiver (http://creativecommons.org/publicdomain/ zero/1.0/) applies to the data made available in this article, unless otherwise stated in a credit line to the data. 
NGR-TNF, a peptide-cytokine conjugate that alters endothelial permeability and enhances the penetration of chemotherapeutic drugs in tumor tissues [3, 7]. Low doses of this drug have been tested in various clinical studies in patients with solid tumors, including patients with primary lymphomas of the central nervous system (PCNSL), with evidence of activity and good tolerability [7, 11-14]. Notably, in these patients, NGR-TNF altered the blood-brain barrier and increased the efficacy of R-CHOP, a chemo-immunotherapeutic regimen $[13,14]$. The therapeutic index of TNF and other cytokines can also be increased by coupling cytokines with colloidal gold $(\mathrm{Au})$, a welltolerated nanomaterial that accumulates in tumors by "passive" targeting mechanisms consequent to the enhanced permeability and retention (EPR) effects of abnormal vessels of tumor tissues [15-19]. We have recently shown that these "active" and "passive" targeting approaches (mediated by peptides and nanogold, respectively) can be combined to generate more efficient cytokine delivery systems. For example, we have shown that NGR-, methylated NGR-, or isoDGRtagged gold nanoparticles represent efficient carriers for delivering TNF or IL12 to tumors [20-23]. Indeed, in animal models of solid tumors, these nanocarriers can deliver pharmacologically active amounts of TNF or IL12 to tumors, with no evidence of toxicity [2023]. However, whether these targeted nanodrugs synergize with chemotherapy remains to be determined. The present study was undertaken to explore the capability of isoDGR-coated nanogold bearing TNF and/or IL12, alone or in combination, to synergize with chemotherapy. The rationale for exploring the TNF/IL12 combination, in addition to TNF alone, relies on the notion that IL12 can induce IFNY in the tumor microenvironment [24, 25], a cytokine known to be critical for the activity of vasculature-targeted TNF [26]. Thus, we prepared gold nanoparticles (Nps) bearing TNF and/or IL12 and c(CGisoDGRG) (iso1), a head-to-tail cyclic peptide that recognizes $\alpha v \beta 3$ integrin overexpressed in the tumor vasculature [27, 28]. We also tested their physicochemical, biochemical and biological properties in vitro and their therapeutic activity in a murine model of fibrosarcoma, alone or combined with doxorubicin (a chemotherapeutic drug). We show that an extremely low dose of nanogold functionalized with iso1 and TNF (bifunctional) or with iso1, TNF and IL12 (trifunctional) can increase the efficacy of doxorubicin without increasing its toxicity. Furthermore, we show that nanogold functionalized with iso1 and TNF increases doxorubicin penetration in tumors a few hours after injection and causes vascular damage at later time points.

\section{Methods}

\section{Reagents}

The following reagents were purchased: human serum albumin (HSA) 20\% solution (Baxter, Deerfield, IL); bovine serum albumin (BSA) (Sigma); human integrin $\alpha v \beta 3$ (Immunological Sciences, Italy); methoxy-PEG-SH (MW $20 \mathrm{KDa}$, PEG) (Nanocs Inc, USA); soluble TNF receptor Type-II (sTNF-R2) fused to the Fc fragment of an IgG1 antibody (Enbrel) (Pfizer, Italy); monoclonal antibody (mAb) anti-IL12/IL23, p40 subunit, clone C15.6 and C17.8 (Biolegend, USA); recombinant murine interleukin-12 (IL12) (PeproTech); and $25 \mathrm{~nm}$ gold (Au) nanospheres (nanogold Aurion). Recombinant murine TNF and synthetic cyclic head-to-tail c(CGisoDGRG) peptide (called iso1) were prepared as described previously [20, 29]. Iso1-HSA conjugate, comprising iso1 chemically coupled to HSA via 4 -( $N$-maleimidomethyl) cyclohexane-1-carboxylic acid 3-sulfo- $N$-hydroxysuccinimide ester sodium salt (sulfo-SMCC) and SMCC-HSA (HSA activated with sulfo-SMCC and quenched with $\beta$-mercaptoethanol in place of iso1), were prepared as described previously [20].

\section{Preparation of bifunctional gold nanoparticles bearing iso 1 and IL12 or iso 1 and TNF}

Bifunctional gold Nps loaded with iso1 and IL12 (called iso1 Au/IL12) or iso1 and TNF (iso1Au/TNF) were prepared, as described previously, by incubating $1 \mathrm{ml}$ of $25-\mathrm{nm}$ nanogold $\left(\mathrm{A}_{520 \mathrm{~nm}}, \sim 1\right.$ unit) with $0.1 \mathrm{ml}$ of solution containing $120 \mu \mathrm{g}$ of iso1-HSA and $2.7 \mu \mathrm{g}$ of IL12 or $160 \mu \mathrm{g}$ of $i s o 1-\mathrm{HSA}$ and $16 \mu \mathrm{g}$ of TNF, respectively [21, 23] (see also Additional file 1: Scheme S1). Monofunctional Nps lacking iso1 (Au/TNF and Au/IL12) were prepared in the same manner, except that SMCC-HSA was used instead of iso1-HSA. Other monofunctional Nps lacking cytokines (iso1 Au) were prepared in the same way by omitting the cytokine in the incubation mixture.

\section{Preparation of trifunctional gold nanoparticles bearing iso 1 , IL12 and TNF}

Trifunctional gold Nps loaded with iso1, IL-12, and TNF (called iso1 Au/TNF + IL12) were prepared as follows: a solution containing $132 \mu \mathrm{g}$ of iso1-HSA, $1 \mu \mathrm{g}$ of TNF (19 pmol), $6 \mu \mathrm{g}$ of IL12 ( $86 \mathrm{pmol}$, corresponding to TNF:IL12 molar ratio of 1:4.5), and $5 \mu \mathrm{g}$ of PEG in $100 \mu \mathrm{l}$ of $5 \mathrm{mM}$ sodium citrate buffer, $\mathrm{pH}$ 6.0, was added to $1 \mathrm{ml}$ of 25-nm nanogold (Aurion), with the $\mathrm{pH}$ adjusted to 4.3-4.4 with orthophosphoric acid (final $\mathrm{pH} \sim 5.5$ ), and left to incubate for $2 \mathrm{~h}$ at room temperature under shaking. The product was mixed with $100 \mu \mathrm{l}$ of $10 \%$ HSA in water (added in aliquots every $2 \mathrm{~min}$ ) and incubated for an additional $5 \mathrm{~min}$ to saturate gold Nps. The final product was centrifuged $\left(14,000 \times g\right.$ for $15 \mathrm{~min}$ at $\left.4{ }^{\circ} \mathrm{C}\right)$, 
resuspended in $1 \mathrm{ml}$ of $1 \% \mathrm{HSA}$ in $5 \mathrm{mM}$ sodium citrate buffer, pH 6.0 (three times), filtered $(0.22 \mu \mathrm{m}$ pore size; Millex-GV Filter) and stored at $-80{ }^{\circ} \mathrm{C}$ (see also Additional file 1: Scheme S1). A similar product was prepared using a TNF:IL12 molar ratio of 4:1. Furthermore, Nps lacking iso1 (called Au/TNF+IL12) were prepared in the same manner, except that SMCC-HSA was used instead of $i$ so1-HSA.

\section{Physicochemical characterization of nanodrugs}

Visible spectra of the nanodrugs were recorded using an UltroSpec 2100 spectrophotometer (Amersham Biosciences) and a 1-cm-path-length quartz cuvette. The concentration of $\mathrm{Nps}$ was calculated by interpolating the $\mathrm{A}_{530} \mathrm{~nm}$ values on a calibration curve obtained using uncoated nanogold in $5 \mathrm{mM}$ sodium citrate buffer, $\mathrm{pH} 6.0$ (stock solution: $3.3 \times 10^{11} \mathrm{Nps} / \mathrm{ml} ; \mathrm{A}_{530} \mathrm{~nm}: 0.96 \mathrm{U} / \mathrm{ml}$ ).

Dynamic light scattering (DLS) measurements were performed using a DLS DYNAPRO 99 instrument (Wyatt) operating with the laser intensity set to $20 \%$ power. The nanodrugs were diluted 1:10 in $5 \mathrm{mM}$ sodium citrate buffer, pH $6.0\left(1-3 \times 10^{10} \mathrm{Nps} / \mathrm{ml}\right)$ and analyzed using 25-30 independent measurements of 10-s duration at $20^{\circ} \mathrm{C}$. The calculation of the hydrodynamic radius of the Nps was performed using DLS regularization analysis.

Transmission electron microscopy (TEM) analysis were performed using a TALOS L120C microscope (ThermoScientific) as described previously [23]. Morphometric analysis of nanoparticles shape and diameter was performed using the ImageJ software, essentially as previously reported [30].

\section{av $\beta 3$ integrin, anti-IL12 antibody and sTNF-R2 binding assays}

The binding assay of nanodrugs to $\alpha v \beta 3$, anti-IL12 antibodies or sTNF-R2 (Enbrel) spotted onto nitrocellulose filters $(0.45 \mu \mathrm{m})$ was performed using a Bio-Dot apparatus (Bio-Rad) as described previously [20, 21, 23]. The $\alpha v \beta 3 /$ anti-IL12 antibody and $\alpha v \beta 3 /$ anti-TNF antibody sandwich assays were performed as described previously [21, 23]. Briefly, various amounts of nanodrugs diluted in binding buffer $(25 \mathrm{mM}$ Tris- $\mathrm{HCl}, \mathrm{pH}$ 7.4, containing $150 \mathrm{mM}$ sodium chloride, $1 \mathrm{mM}$ magnesium chloride, $1 \mathrm{mM}$ manganese chloride $1 \% \mathrm{w} / \mathrm{v}$ BSA) were added to microtiter plates coated with or without $\alpha \mathrm{v} \beta 3(0.5 \mu \mathrm{g} /$ $\mathrm{ml})$. The binding of nanodrugs was then detected using a biotinylated anti-IL12 antibody (anti-p40 subunit; mAb C17.8) or an anti-TNF polyclonal antibody, followed by streptavidin-peroxidase or goat anti-rat antibody-peroxidase conjugates, respectively. Bound peroxidase was detected by adding the o-phenylenediamine chromogenic substrate.

\section{IL12- and PEG-ELISA}

The amount of IL12 and PEG bound to gold Nps was quantified using the MAX Deluxe Set Mouse IL12 (p70) ELISA kit (Biolegend) according to the manufacturer's instructions and the Polyethylene Glycol Backbone ELISA Kit (Life Diagnostics, Inc.) as described previously [23].

\section{In vitro IL12 and TNF bioassay}

The amount of bioactive IL12 bound to gold Nps was determined using an in vitro bioassay based on IL12induced release of IFN $\gamma$ from murine splenocytes [23]. IFN $\gamma$ was detected using the mouse IFN- $\gamma$ DuoSet ELISA kit (R\&D System). The amount of bioactive TNF bound to gold Nps was determined using an in vitro bioassay based on TNF-induced cytolysis of murine L-M fibroblasts, as described previously [29].

\section{In vivo studies}

Murine WEHI-164 fibrosarcoma cells (CRL-1751, ATCC) were cultured in DMEM with standard supplements and tested for mycoplasma contamination before their use in vivo using the MycoAlert assay Control Set (Lonza). BALB/c mice (Charles River Laboratories; 6-8 weeks old), weighing 18 to $20 \mathrm{~g}$, were challenged by s.c. injection into the left flank with $10^{6} \mathrm{WEHI}-164$ cells. Five days later, the mice were injected (i.v.) with nanodrugs in $0.9 \%$ sodium chloride containing $100 \mu \mathrm{g} / \mathrm{ml}$ of HSA, alone or in combination with $150 \mu \mathrm{g}$ of doxorubicin (Adriamycin; Pfizer) in $0.9 \%$ sodium chloride. Tumor growth was monitored by measuring the tumor size with a caliper. The tumor volumes were estimated by calculating $r 1 \times r 2 \times r 3 \times 4 / 3 \pi$, where $r 1$ and $r 2$ are the longitudinal and lateral radii, respectively, and $r 3$ is the thickness of the tumor protruding from the surface of normal skin. Animals were sacrificed before the tumors reached a diameter of $1-1.5 \mathrm{~cm}$. The tumor sizes are shown as the mean \pm SE.

\section{Results}

Gold nanoparticles are loaded with iso1, TNF and/or IL12 to generate bi- or trifunctional nanodrugs

Iso1-coated gold $\mathrm{Nps}$ (iso1 $\mathrm{Au}$ ) bearing different amounts of TNF and IL12 (called iso1Au/TNF+IL12; trifunctional) were prepared by incubating $25-\mathrm{nm} \mathrm{Au}$ nanospheres with solutions containing TNF and IL12 in different molar ratios (1:4.5 or 4:1 molar ratio) and fixed amounts of iso1-albumin conjugate (iso1-HSA) and PEG (see "Methods"). Bifunctional (iso1Au/TNF, iso1Au/ IL12, $\mathrm{Au} / \mathrm{TNF}+\mathrm{IL} 12)$ and monofunctional (Au/TNF and $\mathrm{Au} / \mathrm{IL} 12)$ nanodrugs were also prepared by omitting one or two components, respectively, in the incubation 
mixtures. UV-visible spectrophotometric analysis of the mono-, bi-, and trifunctional products showed similar absorption spectra, as judged from the $\lambda_{\max }$ absorption values, peak width at $75 \%$ height (PW75), and 650/530 nm ratio (Fig. 1a, Additional file 1: Figure S1, and Table 1). Furthermore, dynamic light scattering analysis of bifunctional and trifunctional products showed similar average diameters (approximately 43-44 $\mathrm{nm}$ ) (Table 1 ), suggesting that these nanodrugs essentially consisted of monodispersed Nps. Accordingly, transmission electron microscopy showed that all nanodrugs were made of gold nanospheres with a maximal diameter of about $28 \mathrm{~nm}$ (Additional file 1: Figure S2). Thus, all nanodrugs had very similar physical properties.

To assess whether iso1, TNF and IL12 were indeed loaded on gold Nps, we measured the capability of all the products to bind $\alpha v \beta 3$, sTNF-R2 and anti-IL12 antibodies. We first evaluated the capability of each nanodrug to bind nitrocellulose filters spotted with $\alpha v \beta 3$, sTNF-R2 (Enbrel) or anti-IL12 mAb C15.6. Mono-, bi- and trifunctional nanoparticles recognized spots on nitrocellulose with patterns consistent with their expected functional properties (Fig. 1b). Next, we evaluated the capability of each nanodrug to form molecular sandwiches in two integrin-antibody sandwich assays based on (a) $\alpha v \beta 3$ and anti-IL12 mAb C17.8 and (b) $\alpha v \beta 3$ and polyclonal antiTNF antibodies. As expected, bi- and trifunctional nanoparticles, but not monofunctional nanoparticles, formed molecular sandwiches with $\alpha \mathrm{v} \beta 3$ and relevant anti-IL12 or anti-TNF antibodies in the sandwich assays (Fig. 1c), suggesting that the different components of the bi- and trifunctional nanodrugs are accessible to multivalent heterotypic interactions.

Overall, these results indicate that the bi- and trifunctional nanodrugs were loaded with iso1-HSA, TNF and IL12, as hypothesized, and that iso1 and TNF preserved

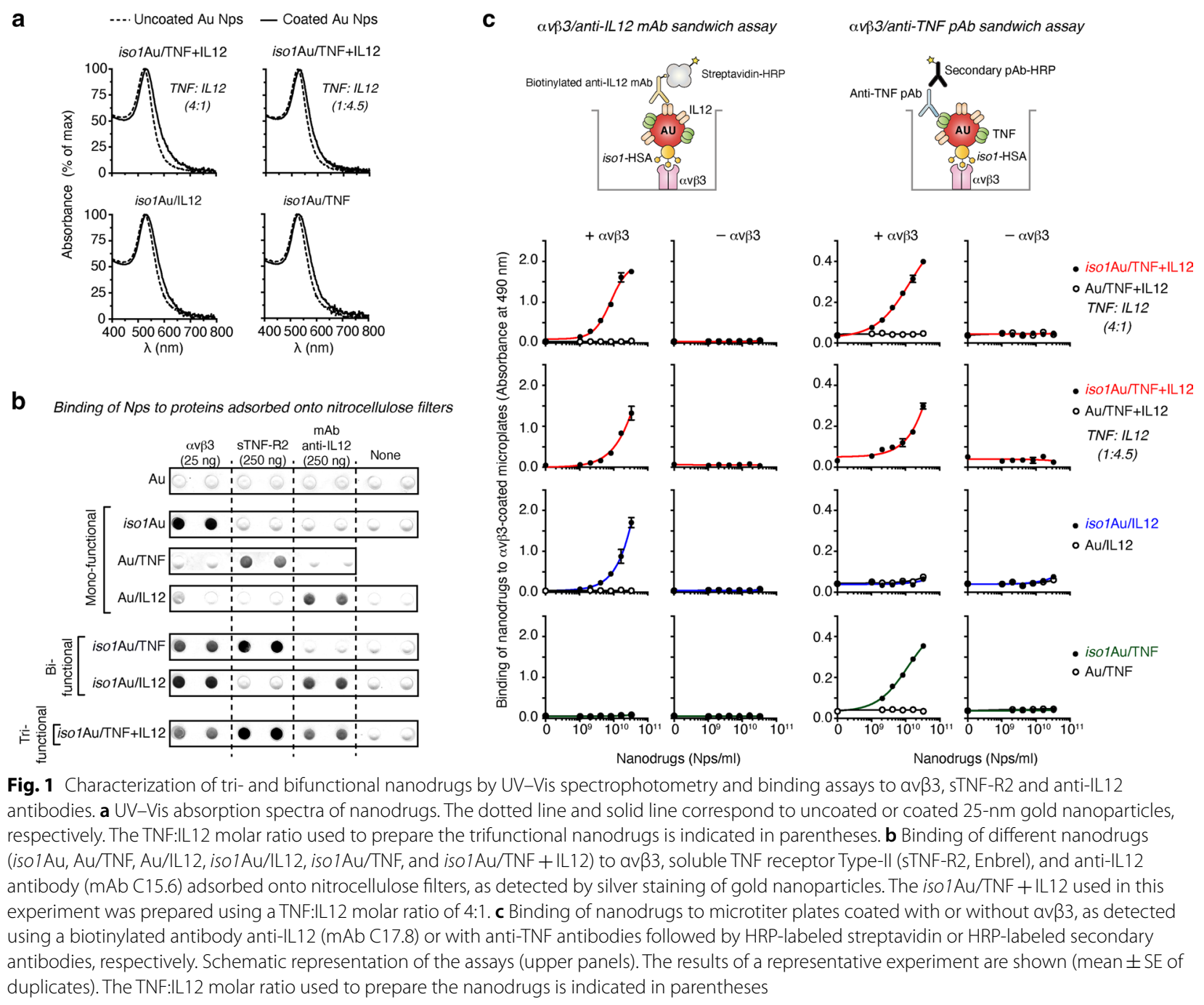


Table 1 Characterization of mono-, bi-, and trifunctional nanodrugs by UV-visible spectroscopy (UV-Vis) and dynamic light scattering (DLS)

\begin{tabular}{|c|c|c|c|c|}
\hline \multirow[t]{2}{*}{ Nanodrug } & \multicolumn{3}{|l|}{ UV-Vis $^{\mathrm{b}}$} & \multirow{2}{*}{$\begin{array}{l}\mathrm{DLS}^{\mathrm{c}} \\
\text { Radius (nm) }\end{array}$} \\
\hline & $\lambda_{\max }(\mathrm{nm})$ & $P W 75 \%$ & $\mathrm{~A}_{650} \mathrm{~nm} / \mathrm{A}_{530} \mathrm{~nm}$ & \\
\hline \multicolumn{5}{|l|}{ Monofunctional } \\
\hline $\mathrm{Au} / \mathrm{IL} 12$ & 528 & 57 & 0.071 & $17.9 \pm 2.3$ \\
\hline $\mathrm{Au} / \mathrm{TNF}$ & $528 \pm 2$ & $58.1 \pm 0.1$ & $0.09 \pm 0.01$ & 22.1 \\
\hline \multicolumn{5}{|l|}{ Bifunctional } \\
\hline isolAu/IL12 & $529.3 \pm 0.9$ & $54.5 \pm 0.7$ & $0.087 \pm 0.02$ & $21.9 \pm 3.2$ \\
\hline isolAu/TNF & $528.6 \pm 0.3$ & $59.0 \pm 0.7$ & $0.095 \pm 0.01$ & $21.6 \pm 3.9$ \\
\hline $\mathrm{Au} / \mathrm{TNF}+\mathrm{IL} 12^{\mathrm{a}}(4: 1)$ & 531 & 52 & 0.111 & - \\
\hline \multicolumn{5}{|l|}{ Trifunctional } \\
\hline isolAu/TNF + IL12 (1:4.5) & $529.0 \pm 1.0$ & $53.9 \pm 0.4$ & $0.113 \pm 0.02$ & $22.11 \pm 2.6$ \\
\hline isolAu/TNF+ IL12a (4:1) & $531.9 \pm 0.9$ & $55.8 \pm 0.3$ & $0.120 \pm 0.01$ & - \\
\hline Uncoated Au Nps & $524.5 \pm 0.6$ & $52.0 \pm 4.0$ & $0.065 \pm 0.02$ & $11.56 \pm 1.4$ \\
\hline
\end{tabular}

a Prepared using the indicated TNF:IL12 molar ratio. See "Methods"

${ }^{b} \lambda$ max: wavelength of peak absorbance; PW 75\%: peak width at $75 \%$ height; $A_{650 \mathrm{~nm}} / \mathrm{A}_{530 \mathrm{~nm}}$ : absorbance ratio. Mean \pm SD of two different preparations

${ }^{c}$ Mean $\pm S D$ of 3 measurements

their receptor binding properties after coupling to nanogold. In other words, nanogold can be successfully loaded with iso1-HSA, TNF and/or IL12.

\section{Assessment of the biological activity of IL12 and TNF loaded on gold nanoparticles}

Next, we quantified the number of IL12 or TNF molecules loaded onto nanogold and assessed their biological activity. Regarding IL12, we measured the capability of iso1 Au/IL12 and iso1 Au/TNF + IL12 to bind anti-IL12 antibodies by sandwich IL12-ELISA (immunoassay) and to promote IFNY release from cultured murine splenocytes (bioassay). Both assays were calibrated with IL12. The immunoreactivity of each bi- or trifunctional nanoparticle was equivalent to that of 5-19 molecules of IL12, depending on the preparation protocol (Table 2). In particular, iso1 Au/IL12 showed 6.4 molecules of IL12/ $\mathrm{Np}$, whereas iso1 Au/TNF + IL12 prepared with $4: 1$ and 1:4.5 molar ratios of TNF/IL12 showed 4.7 and $19.1 \mathrm{~mol}-$ ecules/Np of IL12, respectively. Interestingly, when these drugs were tested using the IFN $\gamma$-release bioassay, their potency was equivalent to 47,35 and 40 molecules/ $\mathrm{Np}$ of IL12, respectively (Table 2). The apparent discrepancy between the immunoassay and bioassay may be due to a more efficient engagement of IL12 receptors by goldbound IL12 compared with "free" IL12, owing to multivalent interactions of each nanoparticle with individual cells. Notably, the $\mathrm{EC}_{50}$ of the two iso1 Au/TNF+IL12 preparations (4:1 and 1:4.5 molar ratios) in the IL12 bioassay corresponded to $4.8 \times 10^{6}$ and $4.2-4.8 \times 10^{6} \mathrm{Nps} /$ $\mathrm{ml}$, respectively, despite the different number of immunoreactive IL12 molecules/Np (Fig. 2 and Table 2).
Considering that 200,000 cells $/ 200 \mu \mathrm{l}$ were seeded in each microtiter plate well, these $\mathrm{EC}_{50}$ values correspond to $4-5 \mathrm{Nps} / \mathrm{cell}$. These data suggest that the binding of a few nanoparticles/splenocyte is sufficient to trigger IFNY release.

To quantify the amount of bioactive TNF loaded onto iso1Au/TNF and iso1 Au/TNF + IL12, we tested their cytotoxic effects against murine $\mathrm{L}-\mathrm{M}$ fibroblasts using TNF as a reference standard. The potency of each iso1 Au/TNF Np was equivalent to that of $6.8 \mathrm{TNF}$ molecules, whereas that of $i s o 1 \mathrm{Au} / \mathrm{TNF}+\mathrm{IL} 12 \mathrm{Nps}$ prepared with 4:1 and 1:4.5 molar ratios of TNF/IL12 was equivalent to 14.1 and 2.4 TNF molecules, respectively (Fig. 2b and Table 2).

Overall, these results establish the feasibility of the multifunctional cytokine nanoformulation based on gold Nps.

\section{Iso $1 \mathrm{Au} / \mathrm{TNF}$, iso $1 \mathrm{Au} / \mathrm{IL} 12$ and iso $1 \mathrm{Au} / \mathrm{TNF}+$ IL12 exert anti-tumor effects in a murine model of fibrosarcoma} We then analyzed the anti-tumor activity of bi- and trifunctional nanodrugs using immunocompetent mice bearing subcutaneous WEHI-164 fibrosarcomas. In previous studies, we found that iso1Au/TNF and iso1 Au/ IL12 exerted maximal anti-tumor activity when injected at doses corresponding to approximately 5-15 pg of TNF $[20,21]$ and $20-70 \mathrm{pg}$ of IL12 [23], respectively. Thus, for in vivo studies, we used iso1 Au/TNF+IL12 prepared using a TNF:IL12 molar ratio of 1:4.5, i.e., with less TNF than IL12 (2.4 and 19.1 molecules/Np, respectively). The administration of doses of iso1Au/TNF, iso1Au/IL12, or iso1 Au/TNF + IL12 equivalent to approximately $10 \mathrm{pg}$ of 
Table 2 Quantification of TNF, IL12 and PEG molecules loaded on gold nanoparticles

\begin{tabular}{|c|c|c|c|c|c|c|c|}
\hline \multirow[t]{3}{*}{ Nanodrug $^{a}$} & \multicolumn{3}{|l|}{ IL12 } & \multirow{2}{*}{\multicolumn{2}{|c|}{$\frac{\text { TNF }}{\text { TNF-Bioassay }^{\mathrm{e}}}$}} & \multirow{3}{*}{\multicolumn{2}{|c|}{$\begin{array}{l}\text { PEG } \\
\text { PEG-ELISA } \\
\text { PEG (molecules/ } \\
\text { Np) }\end{array}$}} \\
\hline & \multirow{2}{*}{$\begin{array}{l}\text { IL12-ELISA } \\
\text { IL12 (molecules/ } \\
\text { Np) }\end{array}$} & \multicolumn{2}{|l|}{ IL12-Bioassay $^{d}$} & & & & \\
\hline & & $\begin{array}{l}\text { IL12 (molecules/ } \\
\mathrm{Np} \text { ) }\end{array}$ & $\mathrm{EC}_{50}(\mathrm{Nps} / \mathrm{ml})$ & $\begin{array}{l}\text { TNF (molecules/ } \\
\mathrm{Np} \text { ) }\end{array}$ & $\mathrm{EC}_{50}(\mathrm{Nps} / \mathrm{ml})$ & & \\
\hline \multicolumn{8}{|l|}{ Bifunctional } \\
\hline iso $1 \mathrm{Au} / \mathrm{IL} 12$ & $6.4 \pm 1.6(n=4)^{c}$ & $47 \pm 10(n=4)$ & $\begin{array}{l}3.6( \pm 0.8) \times 10^{6} \\
(n=4)\end{array}$ & - & - & & $\sim 4(n=1)$ \\
\hline isolAu/TNF & - & - & - & $6.8 \pm 1.0(n=3)$ & $\begin{array}{l}52( \pm 8) \times 10^{6} \\
(n=3)\end{array}$ & & $\sim 3(n=1)$ \\
\hline \multicolumn{8}{|l|}{ Trifunctional } \\
\hline $\begin{array}{l}\text { isol Au/TNF + IL12 } \\
\quad(1: 4.5)\end{array}$ & $19.1 \pm 3.8(n=5)$ & $35 \pm 9(n=4)$ & $\begin{array}{l}4.8( \pm 1.2) \times 10^{6} \\
(n=4)\end{array}$ & $2.4 \pm 0.3(n=7)$ & $\begin{array}{l}146( \pm 22) \times 10^{6} \\
(n=7)\end{array}$ & & $\sim 7(n=1)$ \\
\hline $\begin{array}{l}\text { isol Au/TNF + IL12 } \\
\quad(4: 1)\end{array}$ & $4.7 \pm 0.6(n=8)$ & $40 \pm 7(n=4)$ & $\begin{array}{l}4.2( \pm 0.7) \times 10^{6} \\
\quad(n=4)\end{array}$ & $14.1 \pm 5.1(n=4)$ & $\begin{array}{l}25( \pm 9) \times 10^{6} \\
(n=4)\end{array}$ & & - \\
\hline Protein $^{b}$ & & & $\begin{array}{l}\mathrm{EC}_{50} \text { (molecules/ } \\
\mathrm{ml} \text { ) }\end{array}$ & & $\begin{array}{l}\mathrm{EC}_{50} \text { (molecules/ } \\
\mathrm{ml} \text { ) }\end{array}$ & & \\
\hline IL12 & & - & $\begin{array}{l}169( \pm 40) \times 10^{6} \\
(n=12)\end{array}$ & - & - & - & \\
\hline TNF & - & - & - & - & $\begin{array}{l}352( \pm 9) \times 10^{6} \\
(n=7)\end{array}$ & - & \\
\hline
\end{tabular}

The italic numbers indicate the number of independent experiments

Mean \pm SE

a Prepared as described in "Methods" section. The TNF:IL12 molar ratio used for iso1Au/TNF + IL12 preparation is indicated in parentheses

${ }^{\mathrm{b}}$ Recombinant murine IL12 and TNF

${ }^{c} n$, number of independent experiments

d IL12-induced secretion of IFN $\gamma$ by murine splenocytes (reference standard, recombinant IL12) (see "Methods"). EC 50 : effective concentration 50

e L-M cell cytotoxicity assay (reference standard, recombinant TNF) [29]

TNF or $70 \mathrm{pg}$ of IL12 induced similar anti-tumor effects (Fig. 3, upper panels). Similar anti-tumor effects were also observed using three-fold higher doses (Fig. 3, lower panels). Notably, in previous studies, we have shown that comparable doses of TNF and IL12 were completely inactive in the same model $[20,21,23]$. These data indicate that the iso1 Au nanoformulation of these cytokines increases their anticancer activity. Although no greater effects were observed with the trifunctional Nps in the WEHI-164 fibrosarcoma model, compared to bifunctional Nps, these data indicate that this nanodrug is biologically active in vivo.

\section{Iso1 Au/TNF and iso1 Au/TNF + IL12, but not iso1 Au/IL12, exert synergistic effects with doxorubicin in a murine model of fibrosarcoma}

The capability of bifunctional and trifunctional nanodrugs to synergize with doxorubicin (Doxo) was investigated using the same tumor model. The administration of $150 \mu \mathrm{g}$ of Doxo alone induced a significant delay in tumor growth (Fig. 4a upper panels, and Fig. 4b). This effect was significantly increased when combined with iso1 Au/TNF or iso1 Au/TNF + IL12 but not with iso1 Au/IL12 (Fig. 4a upper panels, and Fig. 4b). None of the tested nanodrugs worsened Doxo-related toxicity, as judged by the animal weight loss (Fig. 4a, lower panels). These results indicate that both bi- and trifunctional Nps bearing TNF can increase the therapeutic index of Doxo.

\section{Iso1 Au/TNF promotes doxorubicin penetration in tumor} tissues and causes vascular damage at later time points The mechanism underlying the anti-tumor activity of iso1Au/TNF and its synergism with Doxo was then investigated. Considering that TNF can increase tumor vascular permeability and reduce drug penetration barriers, we tested the hypothesis that this nanodrug increased Doxo penetration in tumors. To this aim, we exploited the fact that Doxo is a fluorescent compound and that the fluorescence intensity of the tumor cells recovered from animals after treatment indicates the amount of Doxo that penetrated tumors [3]. As expected, iso1 Au/TNF increased the fluorescence intensity and the percentage of positive cells recovered from tumors $2 \mathrm{~h}$ after treatment (Fig. 5). Considering that TNF can also have vascular-damaging effects [31, 


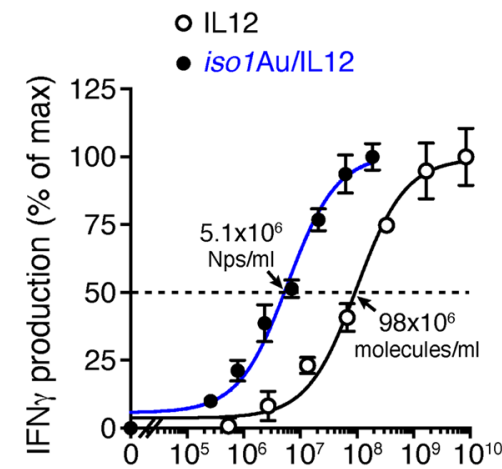

o IL12

- iso1Au/TNF+IL12 (1:4.5)

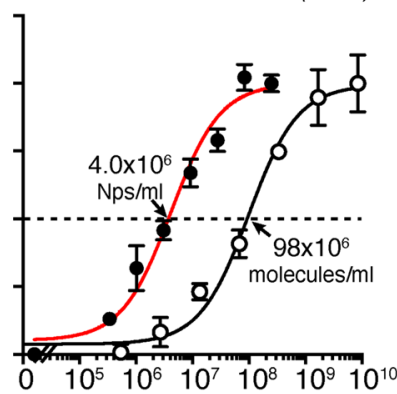

$\mathrm{Nps} / \mathrm{ml}$ or molecules/ml

TNF-Bioassay

\section{b}

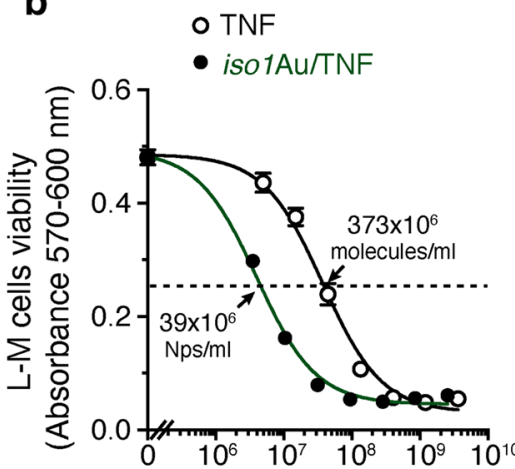

O TNF

- iso1Au/TNF+IL12 (1:4.5)

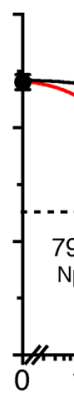

○ IL12

- iso1Au/TNF+IL12 (4:1)

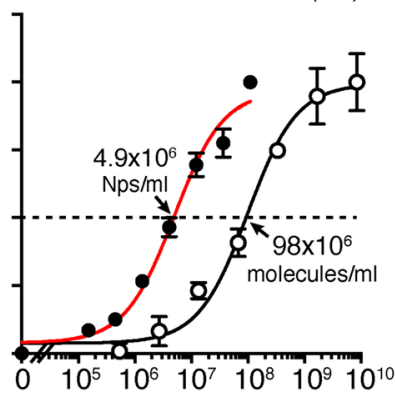

\section{$\mathrm{Nps} / \mathrm{ml}$ or molecules/ml}

Fig. 2 Biological effects of bi- and trifunctional nanodrugs on IFNץ production by splenocytes (a) and L-M cell viability (b). a Effect of nanodrugs and IL 12 on IFNy production by murine splenocytes. Murine splenocytes (200,000 cells in $200 \mu$ l of culture medium) were cultured in complete medium supplemented with $125 \mathrm{U} / \mathrm{ml}$ of IL-2 and variable amounts of nanodrugs or IL 12 for 5 days. IFNy production in pooled cell supernatants (prepared in quadruplicate) was determined by ELISA (in duplicate). One representative experiment is shown (mean $\pm \mathrm{SE}$ ). The cumulative data of 4-12 experiments are reported in Table 2. The TNF:IL12 ratio used to prepare the trifunctional nanodrug is indicated in parentheses. Arrows, effective concentration 50 (EC 50 ). b Cytotoxic effects of nanodrugs and TNF on L-M cells. L-M cells $(30,000$ cells in $100 \mu$ l of culture medium) were cultured in complete medium supplemented with $2 \mu \mathrm{g} / \mathrm{ml}$ of actinomycin D and the indicated amounts of nanodrugs or TNF for $20 \mathrm{~h}$ at $37^{\circ} \mathrm{C}$ and $5 \% \mathrm{CO}_{2}$. Cell viability was quantified using the PrestoBlue Cell Viability Reagent. One representative experiment is shown (mean $\pm \mathrm{SE}$, of triplicates). The cumulative data of 3-7 experiments are reported in Table 2

32], we then analyzed the impact of iso1 Au/TNF on tumor perfusion using contrast-enhanced ultrasound analysis with microbubbles (CEUS). A marked reduction in the signal/time area under the curve (AUC) and peak enhancement of microbubbles was observed 2-3 days after treatment (Fig. 6). This and the above findings suggest that iso1 Au/TNF reduces drug penetration barriers in tumors at early time points, favoring drug extravasation, and causes vascular shutdown at later time points in some tumor areas. Both mechanisms, together with the anti-cancer effects of Doxo, may have contributed to the overall anti-tumor activity of the combined therapy.

\section{Discussion}

This work shows that gold nanospheres coated with the iso1 peptide can be used as a versatile platform for single- or multicytokine delivery to the tumor vasculature. In particular, the results of in vitro studies show that 

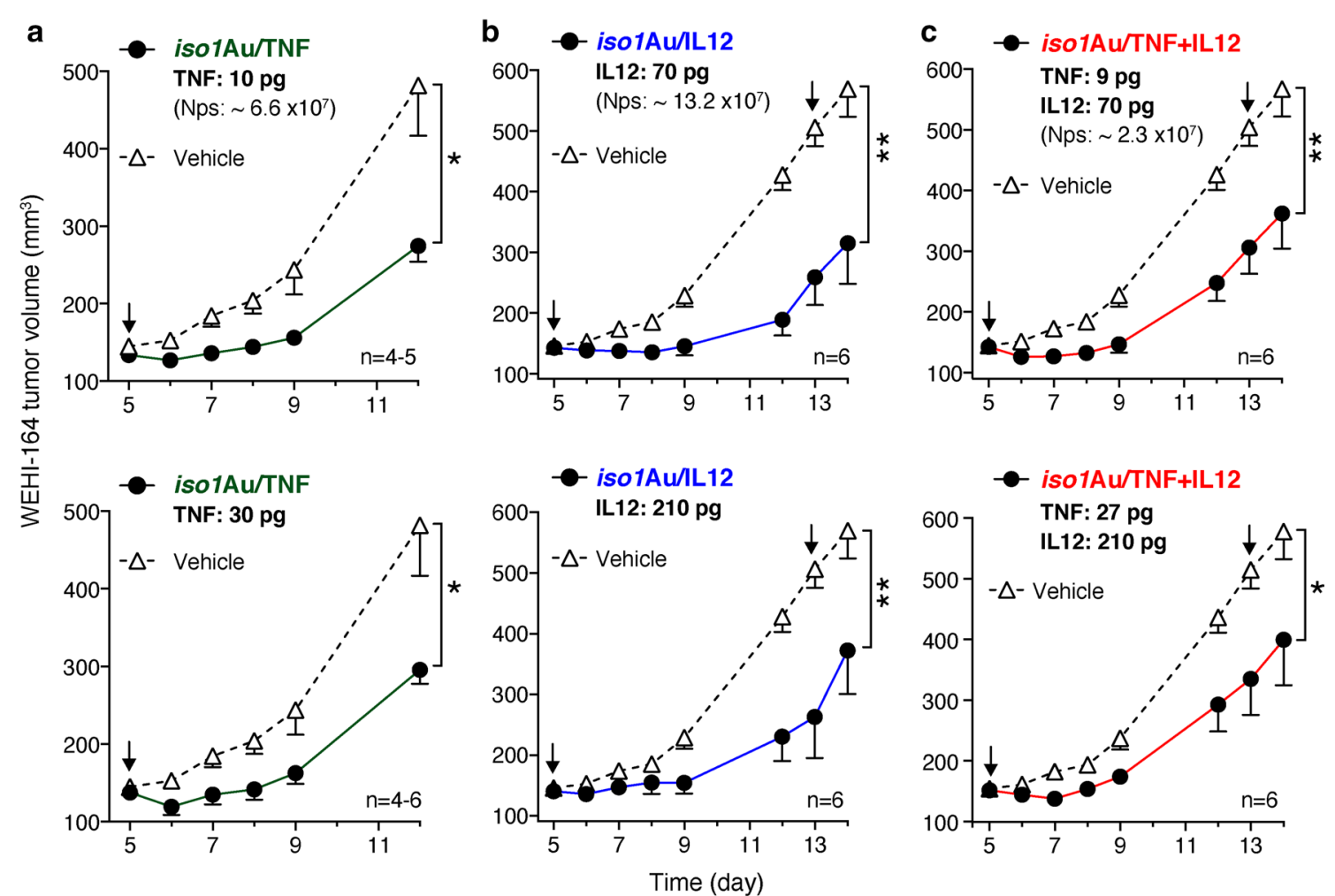

Fig. 3 Anti-tumor effects of bi- and trifunctional nanodrugs in the WEHI-164 fibrosarcoma model. Tumor-bearing mice were treated at the indicated times (arrows) after tumor implantation with the indicated doses of isolAu/TNF (a), isolAu/IL12 (b) or isolAu/TNF+ IL12 (c) (TNF:IL12 molar ratio, 1:4.5) (i.v.). The indicated doses correspond to immunoreactive IL12, as detected by ELISA, or bioactive TNF, as determined by the L-M cytolytic assay. The tumor volumes are shown (mean $\pm \mathrm{SE}, 4-6$ mice per group). ${ }^{*} \mathrm{P}<0.05 ;{ }^{* *} \mathrm{P}<0.01$ by Mann-Whitney analysis of the area under the curve for each tumor with GraphPad Prism software

bi- or trifunctional nanodrugs consisting of nanogold coated with iso1, bioactive TNF and/or IL12 can be easily prepared by incubating 25 -nm gold nanospheres with iso1-HSA, TNF and IL12 in different proportions. Notably, the results of in vitro bioassays show that the "nanoformulated" cytokines (IL12 and TNF) trigger biological effects more efficiently than the corresponding "free" cytokines. For example, 35- to 47-fold lower amounts of nanoformulated IL12, compared to IL12, were sufficient to evoke the secretion of IFNY from murine splenocytes. This phenomenon was not related to iso1-mediated targeting mechanisms of nanoformulated cytokines, because iso1 Au/IL12 and Au/IL12 showed similar potencies in this assay (data not shown). More likely, this phenomenon was related to high-avidity interactions engaged by multivalent nanoparticles with IL12 membrane receptors. Accordingly, enhanced effects have also been observed with TNF upon nanogold formulation.

The enhanced cytokine activity, together with peptide- and gold-mediated active and passive targeting mechanisms (which may occur in vivo), may contribute to reducing the dose of cytokines necessary for inducing pharmacological effects. According to this view, we found that extremely low, nontoxic doses of iso1 Au/ TNF or iso1 Au/TNF + IL12, corresponding to $3-6 \times 10^{7}$ nanoparticles (equivalent to $5-10 \mathrm{pg}$ of TNF), were sufficient to exert synergistic effects with doxorubicin in the WEHI-164 fibrosarcoma model. If we assume that approximately $1 \%$ of the injected dose accumulated in tumors, as typically observed with nanoparticles [33], we estimate that only 3-6 $310^{5}$ nanoparticles reached their target in tumors. Considering that $0.1-$ to $0.2-\mathrm{cm}^{3}$ tumors may contain $1-2 \times 10^{7}$ cells [34], this number of nanoparticles is considerably lower than that of the neoplastic cells present in the tumors at the time of treatment. Endothelial cells, which represent a small fraction of the tumor mass (2-11\%) [21,35] and express the $\alpha v \beta 3$ receptor of iso1 [36, 37], are likely the target of our nanodrugs. Thus, we estimate, from these figures, that the delivery of only 1-4 Nps/endothelial cells is sufficient to induce pharmacological effects. Analysis of doxorubicin uptake by tumor cells, performed $2 \mathrm{~h}$ after treatment with iso1 Au/TNF, showed that this nanodrug enhanced the amount of doxorubicin that reached cancer cells, likely 


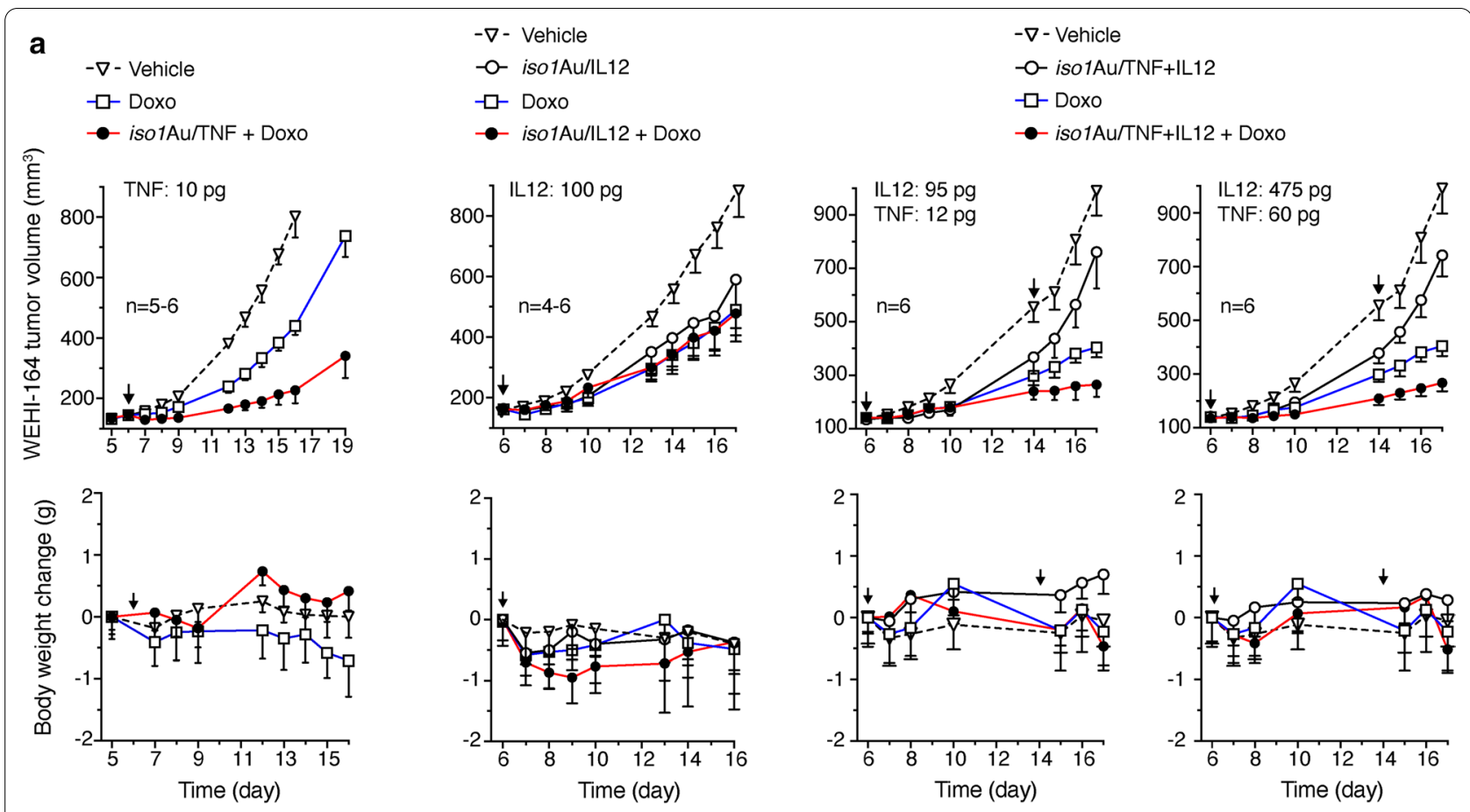

b
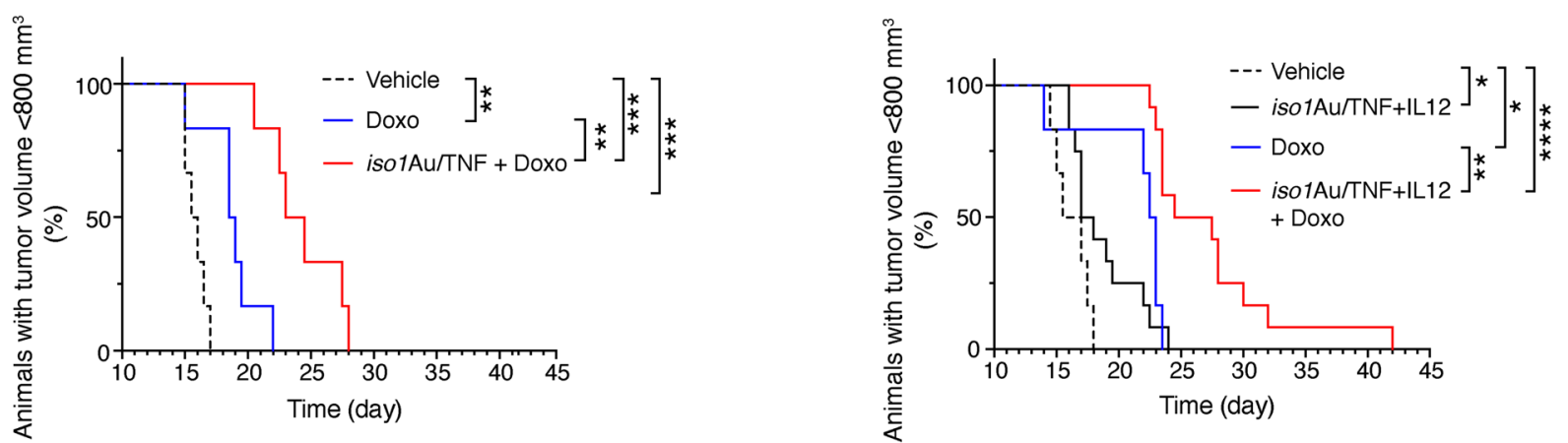

Fig. 4 Effect of bi- and trifunctional nanodrugs alone or in combination with doxorubicin (Doxo). WEHI-164 tumor-bearing mice were treated (i.v.)

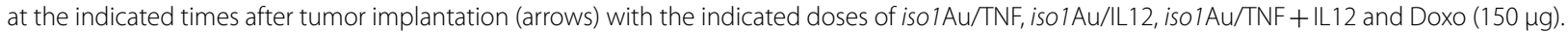
The indicated doses correspond to immunoreactive IL12, as detected by ELISA, or bioactive TNF, as determined by the L-M cytolytic assay. a Tumor volume (upper panels) and body weight changes (lower panels) (mean \pm SE, 4-6 mice per group). b Kaplan-Meier curves of Doxo alone and in combination with iso IAu/TNF or isolAu/TNF + IL12. The cumulative data of the two experiments performed with isolAu/TNF + IL12 (a right panels) are reported. ${ }^{*} \mathrm{P}<0.05 ;{ }^{* *} \mathrm{P}<0.01,{ }^{* * *} \mathrm{P}<0.001,{ }^{* * *} \mathrm{P}<0.0001$ by log-rank (Mantel-Cox) test

by increasing endothelial permeability and reducing drug penetration barriers. However, analysis of tumor perfusion by contrast-enhanced ultrasound 2-3 days after treatment showed that iso1Au/TNF, despite its low dose, could also cause vascular shutdown in some tumor areas. Thus, while iso $1 \mathrm{Au} / \mathrm{TNF}$ can reduce doxorubicin penetration barriers at early time points, at later times this nanodrug may also further entrap doxorubicin in tumor tissues by impairing tumor perfusion. The combination of these time-dependent effects on the tumor vasculature may have contributed to the synergism observed with chemotherapy, resulting in a prolonged survival of mice.

In previous studies, we have shown that low doses of NGR-TNF, a peptide-TNF fusion protein that targets the tumor vasculature, are sufficient to cause the disassembly VE-cadherin dependent-adherence junctions and gap formation in the tumor endothelium, thereby increasing vascular permeability [38]. This compound can also enhance the expression of leukocyte adhesion molecules on tumor endothelial cells and induce cytokine/ chemokine secretion, thereby enhancing lymphocyte 

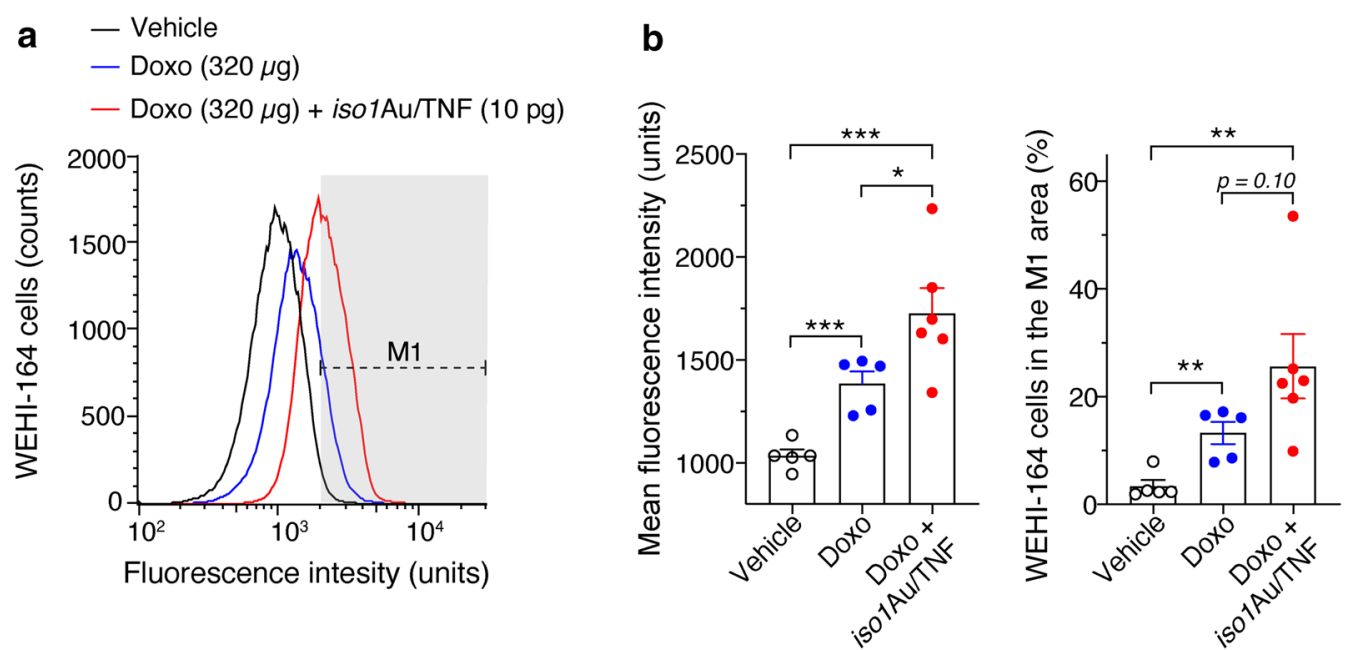

Fig. 5 iso 1Au/TNF increases the tumor cell uptake of Doxo. WEHI-164 tumor-bearing mice (approximately $0.4-0.8 \mathrm{~cm}$ in tumor diameter) were treated i.v. with vehicle or the indicated dose of doxo alone or in combination with iso 1Au/TNF. After $2 \mathrm{~h}$, tumors were recovered, weighed, minced, and processed as described previously [3] to obtain a single-cell suspension, and analyzed by flow cytometry. a Representative flow cytometry analysis of WEHI-164 tumor cells recovered from mice treated as indicated. The M1 dotted line indicates the fluorescence interval considered positive. $\mathbf{b}$ Mean fluorescence intensity (left) and percentage of positive cells in the M1 area (right). Cumulative results of 2 independent experiments (mean $\pm \mathrm{SE}, 2-3$ mice/experiment). ${ }^{*} \mathrm{P}<0.05$; ${ }^{* *} \mathrm{P}<0.01$, ${ }^{* *} \mathrm{P}<0.001$, by two-tailed t-test

infiltration [39]. TNF can also induce endothelial cell apoptosis, vascular damage, intravascular coagulation and occlusion [40], leading to ischemic and hemorrhagic necrosis [41]. These mechanisms are likely triggered also by iso1 Au/TNF, as suggested by the increased doxorubicin uptake, $2 \mathrm{~h}$ after treatment, and by the reduction of tumor perfusion at later time points.

Other investigators have shown previously that $27-\mathrm{nm}$ nanogold functionalized with TNF (called CYT-6091) can suppress tumor perfusion and increase the antitumor effects of chemotherapy in murine models of mammary carcinoma and in genetically engineered mice with pancreatic ductal adenocarcinoma, when administered at doses equivalent to $3-5 \mu \mathrm{g}$ of bioactive TNF [42, 43]. Notably, our results show that markedly lower doses of iso1 $\mathrm{Au} / \mathrm{TNF}$ (equivalent to $5-10 \mathrm{pg}$ of bioactive TNF) are sufficient to affect vascular permeability, tumor perfusion and antitumor efficacy of chemotherapy. The extremely low dose of iso1 $\mathrm{Au} / \mathrm{TNF}$ necessary to induce anti-tumor effects may represent an important advantage in terms of toxicity.

Iso $1 \mathrm{Au} / \mathrm{TNF}$ and iso1 $\mathrm{Au} / \mathrm{TNF}+\mathrm{IL} 12$ showed similar anti-tumor effects in the murine fibrosarcoma model, when used alone or in combination with chemotherapy, suggesting that the addition of IL12 does not increase the anti-tumor effects of iso1Au/TNF in this model. The rationale for combining TNF and IL12 in a single nanodrug (iso1Au/TNF + IL12) relies on the notion that IL12 can induce the release of IFNY from lymphoid cells, such as NK cells and T cells, a cytokine crucial for the activity of low-dose targeted TNF [26]. Furthermore, in previous studies, we showed that low-dose iso1Au/IL12 can significantly increase tumor infiltration by innate immune cells, such as NK and iNKT cells, monocytes, and neutrophils [23]. However, iso1Au/IL12 can also induce the release of sTNF-R2 in the tumor microenvironment, an inhibitor of TNF [23]. We speculate that this mechanism may have counterbalanced, to some extent, the potential synergism of these cytokines when combined in a single drug, such as in the case of iso1Au/TNF+IL12.

In any case, given that the addition of IL12 to iso $1 \mathrm{Au} /$ TNF did not impair its synergism with chemotherapy in the WEHI fibrosarcoma model and considering our previous studies showing that iso1Au/IL12 and TNF can individually support the therapeutic efficacy of adoptive T-cell therapy in other tumor models [23, 44], the trifunctional iso1Au/TNF+IL12 might exert synergistic effects with other chemo-immunotherapeutic combinations in different tumors, which is an approach that merits future investigation.

\section{Conclusion}

We have shown that isoDGR-coated gold nanospheres can be exploited as a versatile platform for single- or multicytokine delivery to cells of the tumor vasculature and that extremely low doses of $i s o$ DGR-coated nanoparticles functionalized with TNF or with TNF + IL12 can induce synergistic effects with doxorubicin. Furthermore, the 


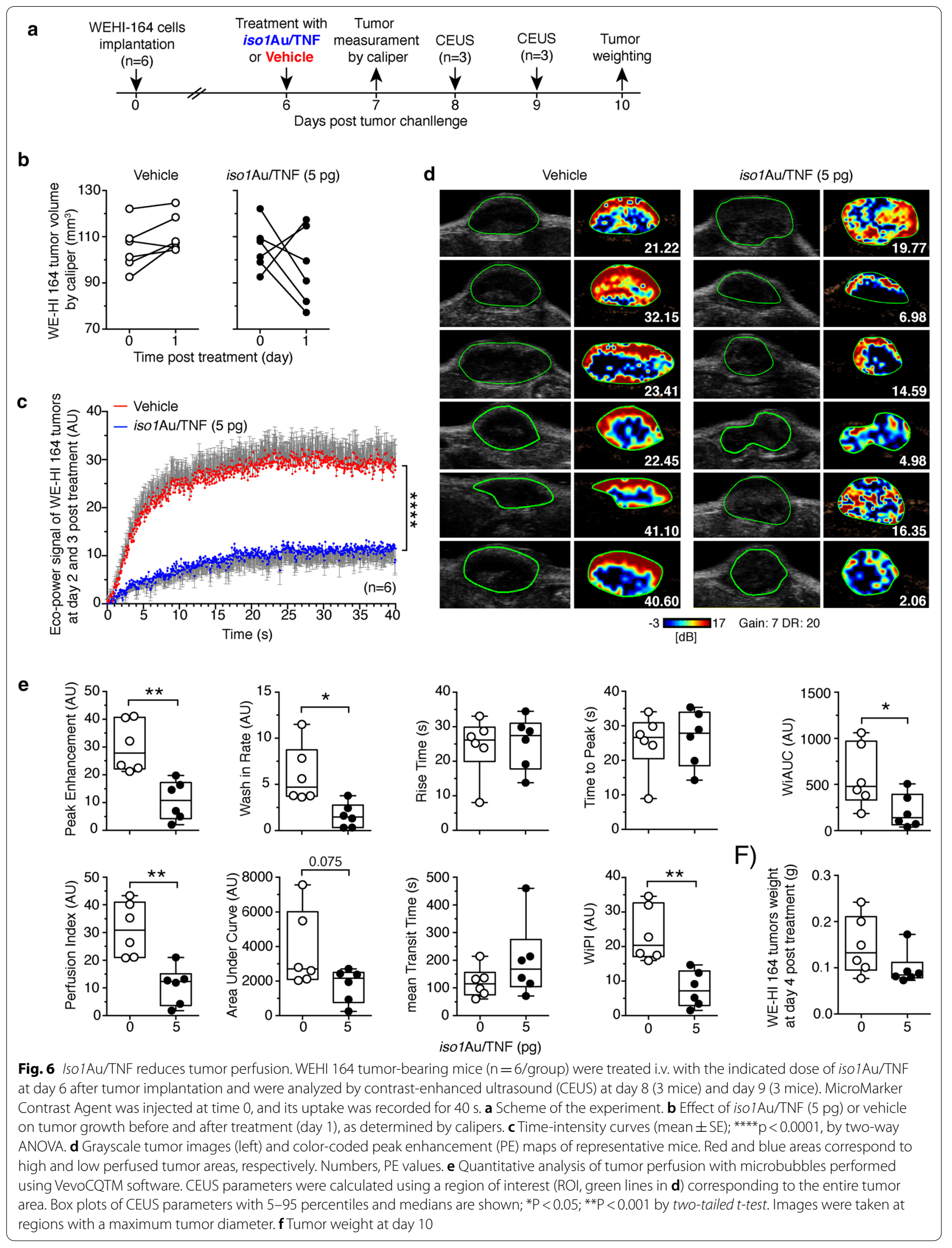


present study establishes the conceptual feasibility of multifunctional cytokine nanoformulations using iso1coated gold nanoparticles, a technology potentially applicable to other cytokines.

\section{Supplementary Information}

The online version contains supplementary material available at https://doi. org/10.1186/s12951-021-00871-y.

Additional file 1: Scheme S1. Schematic representation of the protocol used for preparation of iso 1Au/TNF (A) isolAu/L12 (B) and isolAu/ TNF + IL12 (C). Figure S1. UV-Vis absorption spectra of Au/IL12, Au/TNF and $\mathrm{Au} / \mathrm{TNF}+\mathrm{IL} 12$. Figure $\mathbf{S 2}$. Characterization of iso $\mathrm{Au} / \mathrm{TNF}$, iso $1 \mathrm{Au} / \mathrm{LL} 12$ and iso $1 \mathrm{Au} / \mathrm{TNF}+\mathrm{IL} 12$ by transmission electron microscopy (TEM).

\section{Acknowledgements}

The authors thank Laura Perani, of the Preclinical Imaging Facility (Experimental Imaging Center, San Raffaele Scientific Institute) for CEUS analysis, and Dr. Maria Carla Panzeri (Advanced Light and Electron Microscopy Biolmaging Center, ALEMBIC, San Raffaele Scientific Institute) for TEM analysis.

\section{Authors' contributions}

Conceptualization: AC and FC. Investigation: AMG, AS, AG, FC, AC. Data curation: AMG, AS, BC, GA, MM, AG. Formal analysis: AMG, AS, FC, AC. Writingoriginal draft: AC, FC, AM. Resources: AMG, AS, BC, AG. Supervision: AC and FC. All authors read and approved the final manuscript.

\section{Funding}

This work was supported by Associazione Italiana per la Ricerca sul Cancro (AIRC, grant IG-23470, P.I. A Corti), Fondazione AIRC 5 per Mille 2019 (ID 22737 program, P.I. MC Bonini, Group Leader A Corti) and by Ministero della Salute of Italy (RF-2011-02350836 to AC, and RF-2016-02361054 to FC).

\section{Declarations}

\section{Ethics approval and consent to participate}

All the procedures on mice were approved by the San Raffaele Institutional Animal Care and Use Committee, according to institutional guidelines, and in compliance with national (D.L. N.26, 04/03/2014) and international law and policies (new directive 2010/63/EU). Special attention was given to animal welfare and to minimize animal numbers and suffering.

\section{Consent for publication}

Not applicable.

\section{Competing interests}

$\mathrm{AC}$ and $\mathrm{FC}$ are inventors of a patent regarding iso $1 \mathrm{Au} / \mathrm{LL} 12$ and iso $1 \mathrm{Au} / \mathrm{TNF}$.

\section{Author details}

${ }^{1}$ Tumor Biology and Vascular Targeting Unit, Division of Experimental Oncology, IRCCS San Raffaele Scientific Institute, via Olgettina 58, 20132 Milan, Italy. ${ }^{2}$ Università Vita-Salute San Raffaele, Milan, Italy. Istituto di Scienze e Tecnologie Chimiche, C.N.R., Via Mario Bianco 9, 20131 Milan, Italy. ${ }^{4}$ Lymphocyte Activation Unit, Division of Immunology, Transplantation and Infectious Diseases IRCCS San Raffaele Scientific Institute, Milan, Italy.

Received: 15 February 2021 Accepted: 24 April 2021

Published online: 05 May 2021

\section{References}

1. Conlon KC, Miljkovic MD, Waldmann TA. Cytokines in the treatment of cancer. J Interferon Cytokine Res. 2019;39(1):6-21.
2. Young PA, Morrison SL, Timmerman JM. Antibody-cytokine fusion proteins for treatment of cancer: engineering cytokines for improved efficacy and safety. Semin Oncol. 2014;41(5):623-36.

3. Curnis F, Sacchi A, Corti A. Improving chemotherapeutic drug penetration in tumors by vascular targeting and barrier alteration. J Clin Invest. 2002;110(4):475-82.

4. Pasche N, Neri D. Immunocytokines: a novel class of potent armed antibodies. Drug Discov Today. 2012;17(11-12):583-90.

5. Kontermann RE. Antibody-cytokine fusion proteins. Arch Biochem Biophys. 2012;526(2):194-205.

6. Johansson A, Hamzah J, Payne CJ, Ganss R. Tumor-targeted TNFalpha stabilizes tumor vessels and enhances active immunotherapy. Proc Natl Acad Sci USA. 2012;109(20):7841-6.

7. Corti A, Curnis F, Rossoni G, Marcucci F, Gregorc V. Peptide-mediated targeting of cytokines to tumor vasculature: the NGR-hTNF example. BioDrugs. 2013;27(6):591-603.

8. Zhang B, Gao B, Dong S, Zhang Y, Wu Y. Anti-tumor efficacy and preclinical immunogenicity of IFNalpha2a-NGR. Regul Toxicol Pharmacol. 2011;60(1):73-8.

9. Curnis F, Gasparri A, Sacchi A, Cattaneo A, Magni F, Corti A. Targeted delivery of IFNg to tumor vessels uncouples antitumor from counterregulatory mechanis. Cancer Res. 2005;65(7):2906-13.

10. Ma W, Li G, Wang J, Yang W, Zhang Y, Conti PS, et al. In vivo NIRF imagingguided delivery of a novel NGR-VEGI fusion protein for targeting tumor vasculature. Amino Acids. 2014;46(12):2721-32.

11. Lorusso D, Scambia G, Amadio G, di Legge A, Pietragalla A, De Vincenzo $R$, et al. Phase II study of NGR-hTNF in combination with doxorubicin in relapsed ovarian cancer patients. Br J Cancer. 2012;107(1):37-42.

12. Gregorc V, Gaafar RM, Favaretto A, Grossi F, Jassem J, Polychronis A, et al. NGR-hTNF in combination with best investigator choice in previously treated malignant pleural mesothelioma (NGR015): a randomised, double-blind, placebo-controlled phase 3 trial. Lancet Oncol. 2018;19(6):799-811.

13. Ferreri AJM, Calimeri T, Conte GM, Cattaneo D, Fallanca F, Ponzoni M, et al. $\mathrm{R}$-CHOP preceded by blood-brain barrier permeabilization with engineered tumor necrosis factor-alpha in primary CNS Iymphoma. Blood 2019;134(3):252-62

14. Ferreri AJM, Calimeri T, Ponzoni M, Curnis F, Conte GM, Scarano E, et al. Improving the antitumor activity of R-CHOP with NGR-hTNF in primary CNS lymphoma: final results of a phase 2 trial. Blood Adv. 2020;4(15):3648-58

15. Giljohann DA, Seferos DS, Daniel WL, Massich MD, Patel PC, Mirkin CA Gold nanoparticles for biology and medicine. Angew Chem Int Ed Engl. 2010;49(19):3280-94.

16. Cai W, Gao T, Hong H, Sun J. Applications of gold nanoparticles in cancer nanotechnology. Nanotechnol Sci Appl. 2008;1:17-32.

17. Paciotti GF, Myer L, Weinreich D, Goia D, Pavel N, McLaughlin RE, et al. Colloidal gold: a novel nanoparticle vector for tumor directed drug delivery. Drug Deliv. 2004;11(3):169-83.

18. Libutti SK, Paciotti GF, Byrnes AA, Alexander HR Jr, Gannon WE, Walker $M$, et al. Phase I and pharmacokinetic studies of CYT-6091, a novel PEGylated colloidal gold-rhTNF nanomedicine. Clin Cancer Res. 2010;16(24):6139-49.

19. Powell AC, Paciotti GF, Libutti SK. Colloidal gold: a novel nanoparticle for targeted cancer therapeutics. Methods Mol Biol. 2010;624:375-84.

20. Curnis F, Sacchi A, Longhi R, Colombo B, Gasparri A, Corti A. IsoDGRtagged albumin: a new alphavbeta3 selective carrier for nanodrug delivery to tumors. Small. 2013;9(5):673-8.

21. Curnis F, Fiocchi M, Sacchi A, Gori A, Gasparri A, Corti A. NGR-tagged nano-gold: a new CD13-selective carrier for cytokine delivery to tumors. Nano Res. 2016;9(5):1393-408.

22. Corti A, Gasparri AM, Ghitti M, Sacchi A, Sudati F, Fiocchi M, et al. Glycine $\mathrm{N}$-methylation in NGR-tagged nanocarriers prevents isoaspartate formation and integrin binding without impairing CD13 recognition and tumor homing. Adv Funct Mater. 2017;27(36):1701245.

23. Gasparri AM, Sacchi A, Basso V, Cortesi F, Freschi M, Rrapaj E, et al. Boosting interleukin-12 antitumor activity and synergism with immunotherapy by targeted delivery with isoDGR-tagged nanogold. Small. 2019;15(45):e1903462. 
24. Trinchieri G. Interleukin-12: a proinflammatory cytokine with immunoregulatory functions that bridge innate resistance and antigen-specific adaptive immunity. Annu Rev Immunol. 1995;13:251-76.

25. van Herpen CM, van der Voort R, van der Laak JA, Klasen IS, de Graaf AO, van Kempen LC, et al. Intratumoral rhlL-12 administration in head and neck squamous cell carcinoma patients induces B cell activation. Int J Cancer. 2008;123(10):2354-61.

26. Sacchi A, Gasparri A, Curnis F, Bellone M, Corti A. Crucial role for interferon-gamma in the synergism between tumor vasculature-targeted tumor necrosis factor alpha (NGR-TNF) and doxorubicin. Cancer Res. 2004;64(19):7150-5.

27. Brooks PC, Stromblad S, Klemke R, Visscher D, Sarkar FH, Cheresh DA. Antiintegrin alpha $v$ beta 3 blocks human breast cancer growth and angiogenesis in human skin. J Clin Invest. 1995;96(4):1815-22.

28. Avraamides CJ, Garmy-Susini B, Varner JA. Integrins in angiogenesis and lymphangiogenesis. Nat Rev Cancer. 2008;8(8):604-17.

29. Curnis F, Corti A. Production and characterization of recombinant human and murine TNF. Methods Mol Med. 2004;98:9-22.

30. Rice SB, Chan C, Brown SC, Eschbach P, Han L, Ensor DS, et al. Particle size distributions by transmission electron microscopy: an interlaboratory comparison case study. Metrologia. 2013;50(6):663-78.

31. Lejeune F, Lienard D, Eggermont A. Regional administration of recombinant tumour necrosis factor-alpha in cancer, with special reference to melanoma. BioDrugs. 1998;9(3):211-8.

32. Lejeune FJ, Lienard D, Matter M, Ruegg C. Efficiency of recombinant human TNF in human cancer therapy. Cancer Immun. 2006;6:6.

33. Wilhelm S, Tavares AJ, Dai Q, Ohta S, Audet J, Dvorak HF, et al. Analysis of nanoparticle delivery to tumours. Nat Rev Mater. 2016;1:16014.

34. Del Monte U. Does the cell number 10(9) still really fit one gram of tumor tissue? Cell Cycle. 2009;8(3):505-6.

35. Baeten CI, Wagstaff J, Verhoeven IC, Hillen HF, Griffioen AW. Flow cytometric quantification of tumour endothelial cells; an objective alternative for microvessel density assessment. Br J Cancer. 2002;87(3):344-7.

36. Alghisi GC, Ruegg C. Vascular integrins in tumor angiogenesis: mediators and therapeutic targets. Endothelium. 2006;13(2):113-35.
37. Friedlander M, Brooks PC, Shaffer RW, Kincaid CM, Varner JA, Cheresh DA. Definition of two angiogenic pathways by distinct alpha $v$ integrins. Science. 1995;270(5241):1500-2.

38. Dondossola E, Gasparri AM, Colombo B, Sacchi A, Curnis F, Corti A. Chromogranin A restricts drug penetration and limits the ability of NGR-TNF to enhance chemotherapeutic efficacy. Cancer Res. 2011;71(17):5881-90.

39. Calcinotto A, Grioni M, Jachetti E, Curnis F, Mondino A, Parmiani G, et al. Targeting TNF-alpha to neoangiogenic vessels enhances lymphocyte infiltration in tumors and increases the therapeutic potential of immunotherapy. J Immunol. 2012;188(6):2687-94.

40. Nawroth P, Handley D, Matsueda G, De Waal R, Gerlach H, Blohm D, et al. Tumor necrosis factor/cachectin-induced intravascular fibrin formation in meth A fibrosarcomas. J Exp Med. 1988;168(2):637-47.

41. North RJ, Havell EA. The antitumor function of tumor necrosis factor (TNF) II. Analysis of the role of endogenous TNF in endotoxin-induced hemorrhagic necrosis and regression of an established sarcoma. J Exp Med. 1988;167(3):1086-99.

42. Visaria RK, Griffin RJ, Williams BW, Ebbini ES, Paciotti GF, Song CW, et al. Enhancement of tumor thermal therapy using gold nanoparticle-assisted tumor necrosis factor-alpha delivery. Mol Cancer Ther. 2006;5(4):1014-20.

43. Libutti SK, Tamarkin L, Nilubol N. Targeting the invincible barrier for drug delivery in solid cancers: interstitial fluid pressure. Oncotarget. 2018;9(87):35723-5

44. Manzo T, Sturmheit T, Basso V, Petrozziello E, Hess Michelini R, Riba M, et al. T cells redirected to a minor histocompatibility antigen instruct intratumoral TNFalpha expression and empower adoptive cell therapy for solid tumors. Cancer Res. 2017:77(3):658-71.

\section{Publisher's Note}

Springer Nature remains neutral with regard to jurisdictional claims in published maps and institutional affiliations.
Ready to submit your research? Choose BMC and benefit from:

- fast, convenient online submission

- thorough peer review by experienced researchers in your field

- rapid publication on acceptance

- support for research data, including large and complex data types

- gold Open Access which fosters wider collaboration and increased citations

- maximum visibility for your research: over $100 \mathrm{M}$ website views per year

At BMC, research is always in progress.

Learn more biomedcentral.com/submissions 